\title{
Review: Saltwater intrusion in fractured crystalline bedrock
}

\author{
Markus Giese $^{1}$ (D) Roland Barthel $^{1}$
}

Received: 25 March 2021 / Accepted: 10 August 2021 / Published online: 31 August 2021

(C) The Author(s) 2021

\begin{abstract}
During the past few years, the number of regional and national assessments of groundwater quality in regard to saltwater intrusion in coastal aquifers has increased steadily. However, most of the international literature on saltwater intrusion is focused on coastal plains with aquifers in unconsolidated material. Case studies, modelling approaches and parameter studies dealing with saltwater intrusion in those systems are abundant. While the hydrogeology of fractured rock has been intensively studied with both modelling approaches and parameter studies - mainly in relation to deep-laying fractured crystalline bedrock as potential waste repositories - case studies on saltwater intrusion in shallow fractured rocks are still an exception. This review summarizes the actual knowledge on saltwater intrusion in fractured crystalline rock. In combination with short overviews of the processes of saltwater intrusion, flow in fractured systems and the genesis of these systems, the review highlights the importance of the fracture systems and its specific characteristics. Fracture properties are a direct consequence of the geological history as well as the current situation of the coastal area. A holistic assessment of water quality in coastal areas hosting fractured crystalline bedrock therefore requires the combination of different approaches in order to investigate the impact of saltwater intrusion through the fractured system.
\end{abstract}

Keywords Saltwater intrusion $\cdot$ Salt-water/fresh-water relations $\cdot$ Crystalline rocks $\cdot$ Fractured rocks $\cdot$ Coastal aquifers

\section{Introduction}

During the last two decades, the groundwater situation has worsened in coastal areas around the globe. Additional to (over)exploitation of the water resources in densely populated and economically stressed coastal areas, these areas are facing new challenges related to globalization such as global migration and world-market trading, as well as the current security situation rerouting tourist flows (Post and Werner 2017). Especially during summer seasons, increased water demand due to mass tourism and agricultural water consumption can lead to a modification of the natural seawater-freshwater interaction and eventually to saltwater intrusion (SWI) into the coastal aquifer (Custodio 2010). The increasing number of regional studies or national review papers on saltwater intrusion (e.g. Werner 2010; Barlow and Reichard 2010; Carreira et al. 2014; Shi and Jiao 2014; Manivannan and Elango 2019; Jasechko et al.

Markus Giese

markus.giese@gu.se

1 Department of Earth Sciences, University of Gothenburg, Gothenburg, Sweden
2020; Idowu and Lasisi 2020; Jeen et al. 2021) affords the conclusion that this is a globally emerging problem.

The complexity of SWI can be simplified by regarding different directions of the saltwater encroachment separately. The direction is highly correlated to the dominating processes caused by both natural and anthropogenic factors. Lateral and upward SWI is mainly triggered by changes of the systems' boundary conditions, which are not constant over time. Onshore, the freshwater recharge is subject to seasonal as well as long-term fluctuations (i.e. climatic variations causing changes in groundwater recharge). Anthropogenic activities in coastal regions increase the naturally existing threat of SWI into the aquifer system. Especially the risk of upward SWI increases due to the (over)exploitation of freshwater resources, referred to as upconing (Reilly and Goodman 1987). Downward SWI is caused by saltwater inflow from the surface due to temporary (e.g. storm floods) or permanent (e.g. estuaries, marsh flats) saltwater flooding (Barlow and Reichard 2010). Persistent changes of the boundary conditions, i.e. sea level rise, have lasting effects on these dynamics. For a wide range of settings, coastal regions are more vulnerable to SWI caused by groundwater (over)exploitation than to SWI as a consequence of predicted sea level rise (Ferguson and Gleeson 2012). 
The intrusion of saltwater is causing severe problems related to agricultural and domestic usage of coastal water resources. For example, already a freshwater-seawater mixture containing $1.3 \%$ marine saltwater exceeds the EU drinking water standard for chloride ( $250 \mathrm{mg} / \mathrm{L}$; EU 2020), assuming an average chloride concentration of seawater $(19,000 \mathrm{mg} / \mathrm{L}$; Barlow 2003). The term SWI defines the saltwater encroachment in an aquifer and should clearly be differentiated from other processes resulting in salt-enriched water. A few sources of salinity worth mentioning are immobile water from earlier transgressions, anthropogenic pollution (e.g. industrial effluents, road de-icing salts and land use activities like irrigation) and natural dissolution of rock salt (e.g. Allen et al. 2002; Allen 2004; Barlow 2003; Barlow and Reichard 2010).

Avoiding permanent damage to the freshwater resources requires sustainable management practices that do not always exist for coastal aquifer systems (Post and Werner 2017). One example of a lack of sustainable management involves the coastal areas of Sweden. Groundwater problems in coastal regions are usually not associated with the relatively sparsely populated but freshwater-rich countries in Scandinavia; however, the combination of geology and the specific conditions of water usage create challenges even there. Approximately one third of the Swedish population lives in coastal areas ( $<5 \mathrm{~km}$ away from the coastline; Svanström 2012) where groundwater often occurs in fractured crystalline bedrock or in relatively small, shallow, and isolated Quaternary sedimentary formations. A large number of the approximately 450,000 private wells in Sweden are located in these coastal areas or on islands (Maxe 2007; Earon and Olofsson 2020). The wells create pressure on groundwater resources in summer months due to the low natural groundwater recharge and increased water demand as a consequence of tourism or seasonal increase of population. In densely populated areas, like the Stockholm Archipelago, reports on drilled wells already mention saltwater intrusion in fractured crystalline bedrock due to overexploitation in the early 1980s (Sund and Bergman 1981).

International research on SWI mainly focuses on aquifers in unconsolidated sediments, including most of the developed approaches to investigate and mitigate SWI. It might be a fact of missing relevance to global water supply that quantitative analyses as well as conceptual approaches are lacking for SWI in fractured rock (Barlow 2003; Werner et al. 2013) but reports from different coastal areas have been mentioning SWI in fractured rocks caused by natural (e.g. Carr 1969) as well as anthropogenic factors (e.g. Tremblay et al. 1973) for several decades. Compared to other types of consolidated rock, for example limestone (e.g. Fleury et al. 2007), comprehensive overviews of SWI in fractured crystalline bedrock are still missing. Potentially affected coastal areas consisting of plutonics and metamorphics are highlighted in Fig. 1, which is based on the global lithographic map GLiM (Hartmann and Moosdorf 2012).
Werner et al. (2013) point out that (well-documented) case studies are of prime importance for research related to SWI. This might be especially true for fractured crystalline bedrock where SWI is closely connected to the geometry and orientation of the fracture system (Caswell 1979). The global dimension of problems caused by SWI in fractured crystalline bedrock - accounting for approximately $22 \%$ of the world's coastal lithology (see the table in the Appendix) - is largely obscured. Therefore, the aim of this study is to collect and analyse the internationally available literature on SWI in fractured crystalline bedrock. The collection encompasses studies that evaluate the status of SWI in crystalline bedrock and summarizes tools as well as approaches for a holistic SWI investigation. In combination with a general overview of fractured rocks and SWI, the collected studies will be used to not only point out the current research status, but also the missing links regarding the comprehensive analysis of SWI in fractured crystalline bedrock aquifers.

This paper summarizes the most important and theoretical aspects and processes of SWI in general, with a focus on those most relevant in crystalline bedrock. There is focus on the genesis of fracture systems in crystalline host rocks defining the specific hydrogeological properties. The status of practical knowledge is then illustrated by presenting actual studies carried out in relation to SWI in crystalline bedrock, and insights from related research which can directly or indirectly be applied to questions about SWI in crystalline bedrock, are summarized.

\section{Processes related to saltwater intrusion}

First reports on natural SWI date back more than 150 years (cf. Back and Freeze 1983; Custodio 2010; Houben and Post 2017). The first general scientific descriptions of SWI were published at the end of the nineteenth century. Based on field observations, Drabbe and Badon-Ghijben (1888) and Herzberg (1901) derived the first quantitative relationship of the saltwater-freshwater interface location as a linear function of the water-table elevation in steady-state conditions. The resulting conceptual theorem, the Ghijben-Herzberg theorem, is named after two of the leading authors. The conceptual model of a sharp interface is still frequently applied, although it does not account for mixing along the interface and therefore simplifies the problem (e.g. Mehdizadeh et al. 2017; Siena and Riva 2018). Whereas a sharp interface approximation can be applied under certain conditions (cf. Bear 1979), measurements in different coastal zones indicate a great spatial extension of a mixing zone between fresh and saltwater (e.g. Xue et al. 1993; Barlow 2003). Therefore, the validity of a sharp interface applied on real case scenarios is already limited in unconsolidated material (e.g. Reilly and Goodman 1985; Pool and Carrera 2011; Llopis-Albert and Pulido- 
Fig. 1 Global coastal lithographic map excluding Antarctica: Red line indicates plutonics and metamorphics, black line the other first-level lithological classes (based on Hartmann and Moosdorf 2012). A detailed map can be found in the Appendix

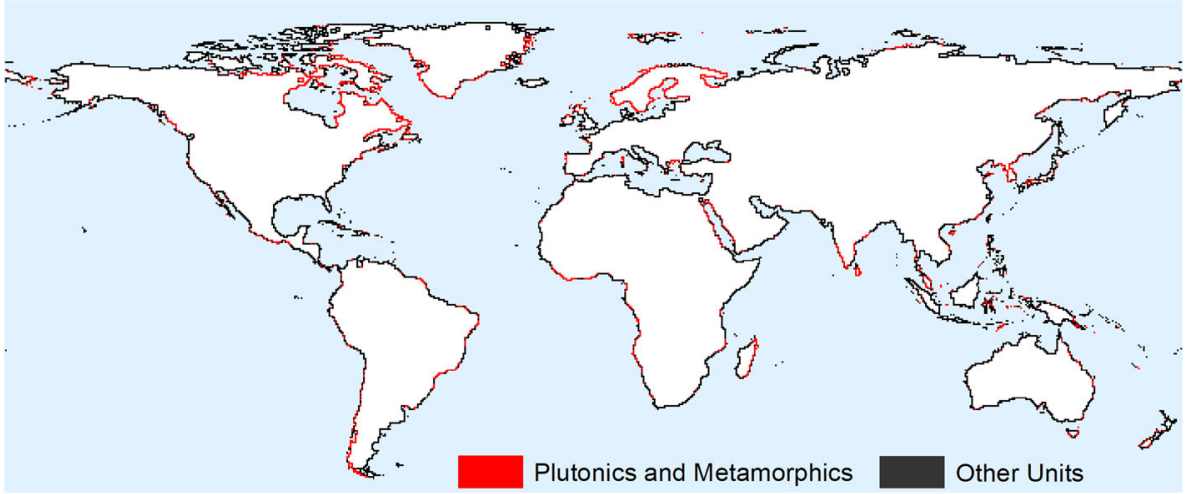

Velazquez 2014; Siena and Riva 2018). Nevertheless, the application of the sharp interface approximation for sustainable water-resources management is a conservative measure, since it overestimates the frontal extent of the SWI and underestimates critical pumping rates (Pool and Carrera 2011).

The mixing zone describes a salinity concentration gradient zone between saltwater and fresh water due to dispersion, i.e. hydrodynamic dispersion and molecular diffusion (e.g. Cooper 1959; Allen et al. 2002; Werner et al. 2013). Along the gradient where concentration and fluid density varies between the two end-members (Lu and Luo 2010), groundwater flow is not static but flows in a vertical convection cell (density driven) transporting deep saltwater into the mixing zone (Cooper 1959). Hydrodynamic dispersion describes the effect of heterogeneity in a flow velocity distribution and plays a significant role in the changes and development of the lateral extent of the mixing zone (Abarca et al. 2007; Lu and Werner 2013). Hydrodynamic dispersion depends on the properties of the flowing media and is nonuniform. According to Abarca et al. (2007), longitudinal and transverse dispersion control the extent of the mixing zone on a larger scale. In dynamic systems and systems with larger dispersion coefficients, the mixing zone is generally thicker (Lu and Luo 2010; Lu and Werner 2013).

Particularly heterogeneous aquifers and hence fractured aquifers show a high variation in the location and spatial extension of the mixing zone (Allen et al. 2002). Especially on a local scale, system heterogeneity can have a strong effect along preferential flow paths (Werner et al. 2013), which needs to be assessed on a regional scale, e.g. by effective parameters in groundwater flow models (Post 2005). However, the principles and processes influencing the spatial extent of mixing zones are complex and not fully understood (e.g. Reilly and Goodman 1985; Lu et al. 2009; Werner et al. 2013), ranging from transient boundary conditions (short- and long-term) over hydraulic properties of the coastal region to anthropogenic influences (e.g. Cooper 1959; Allen et al. 2002; Michael et al. 2005; Lu et al. 2009; Werner et al. 2013). Spatiotemporal changes in salinity directly affect the density, so that groundwater flow in coastal aquifers cannot be considered without solute transport (e.g. Dentz et al. 2006; Post and Abarca 2010). In fractured systems, groundwater flow depends on the heterogeneity of the permeability distribution, which is normally unknown. Solute transport in fractured systems is poorly predictable due to the complexity and scale-dependency of several involved processes (e.g. hydrodynamic dispersion, diffusion, density driven flow). The physical processes of flow and transport in single fractures are known (Bodin et al. 2003a), which also explains the abundance of different numerical approaches on the scale of single fractures (e.g. Bodin et al. 2003b); however, studies on density effects on flow and solute transport are still scarce.

Hydraulic dispersion in a fracture consists of three different mechanisms (Bodin et al. 2003a): Taylor dispersion, roughness dispersion and dispersion as a consequence of aperture variations. The Taylor dispersion describes the parabolic cross-sectional velocity distribution between the fracture walls in laminar flow conditions (Taylor 1953). Taylor dispersion depends both on the properties of the fracture (i.e. the fracture aperture) and on the properties of the flowing media (i.e. diffusion coefficient and mean velocity; Zhou et al. 2007). Hydrodynamic dispersion needs to be considered at a local scale as well as on the scale of fracture systems, due to variation of fracture width (Bodin et al. 2003a). These variations along the flow path also favour channelized or preferential flow on both scales (Tsang and Neretnieks 1998). In general, preferential flow develops along flow paths with the lowest hydraulic resistance (Tsang and Tsang 1989), resulting in heterogeneous advection, as a consequence of the distribution of the flow velocity in the fracture system. Within fractured systems, the activation of flow paths is related to flow conditions (i.e. baseflow, high flow) and therefore short-term changes in boundary conditions (Gentry and Burbey 2004). Due to the low porosity of unweathered crystalline bedrock, neglecting matrix diffusion might be valid (e.g. Guihéneuf et al. 2017); however, shallow crystalline bedrock exposed to extensive weathering might have an increased porosity circumjacent to the fractures where matrix diffusion is significant (Ohlsson and Neretnieks 1995); more details on solute transport in single fractures are provided by Bodin et al. (2003a). 


\section{Characteristics of fractured (crystalline) bedrock}

Starting with the conceptual description of flow and solute transport in fractured rock by Snow (1965), fractured rock formations received attention as potential groundwater resources and waste repositories. This resulted in an increasing number of case studies supported by numerical groundwater modelling to better understand the groundwater flow in (crystalline) fractured rocks. Nevertheless, the primary purpose and focus of these studies were safety assessments for (toxic or radioactive) waste repositories in deep-lying crystalline bedrock (e.g. MacQuarrie and Mayer 2005; Tsang et al. 2015). The other major group of publications focusses on the numerical description of processes and effects of idealised or generalised heterogeneity, including fractures, connected to SWI or submarine groundwater discharge (e.g. Kerrou and Renard 2010; Lu et al. 2013; Sebben et al. 2015; Etsias et al. 2021). In general, literature related to hydrogeological aspects of fractures is abundant (Berkowitz 2002); hence, the following paragraphs will focus on properties in the topmost approximately $300 \mathrm{~m}$ of coastal areas, representing the typical depth of groundwater wells, and processes directly related to SWI in fractured crystalline bedrock.

Fractures are defined as generic discontinuities in bedrock that occurred in response to stress. During geologic history, different periods of stress distributions formed different fracture types in different types of bedrock, and hence shaped the properties influencing water flow (i.e. permeability; e.g. Banks et al. 1996; Evans et al. 1997; Baghbanan and Jing 2008). These stress distributions can be divided into three main groups (Banks et al. 1996): (1) paleo-stress fields that initially are evolving water-bearing fracture systems; (2) current in situ stress fields reshaping the existing fracture systems and (3) anthropogenic stress fields, caused by, e.g. fracking or explosions, influencing natural flow fields on a local scale. Stress in subsurface rocks can be forced by regional (e.g. pressure of overlaying bedrock) and global (e.g. tectonic) activities influencing unique characteristics such as the orientation and geometry of fractures. In general, fractures can be divided into two different classes, namely joints and faults (Berkowitz 2002). The differentiation is related to the processes forming the discontinuity and the resulting properties. Faults are the result of large-scale tectonic events, and therefore, if originating from the same event, are similar in orientation, which reduces the interconnection (Berkowitz 2002). The significance of fault zones on the regional water flow depends on several factors, foremost the orientation of the fault towards the general groundwater flow direction. Several other factors and the general structure of fault zones and their influence on groundwater flow are detailed in Caine et al. (1996), Evans et al. (1997), Gudmundsson (2000), Bense et al. (2013) and Roques et al. (2014).
Joints result from regional processes and are in general well connected due to their coverage and manifold orientation (Berkowitz 2002). One example of a regional process is the isostatic uplift of Fennoscandia (e.g. Dehls et al. 2000; Eronen 2005), which is expected to influence the differences of rock fracturing on a regional scale (e.g. Rohr-Torp 1994). Other in situ stresses on a regional scale are, for example, topographic anomalies, geological discontinuities, erosion or fluid pressure (Banks et al. 1996; Berkowitz 2002). In case the in situ stress equals or exceeds the mechanical strength of the bedrock, new fractures develop along the principle stresses of the stress field (e.g. Henriksen and Braathen 2006). In the shallow part of the bedrock, anisotropic stress fields result in a large range of fracture width (Banks et al. 1996). The abundance of fractures in the host rock decreases with depth up to 100 $300 \mathrm{~m}$ below surface (Rutqvist 2015), due to prevailing isotropic stress in deep-lying bedrock (Acworth 1987). However, the actual state and evolution of the stress field has a large impact on the fracture closure, and therefore the hydrogeological properties of the single fracture as well as the hydraulics of the fracture system (e.g. Sayers 1990; Banks et al. 1996; Baghbanan and Jing 2008).

Stress fields, for example introduced by topographic anomalies, have a direct relationship to rock weathering (St. Clair et al. 2015). With an increasing number of open fractures, the vulnerability of the bedrock to weathering also increases (Acworth 1987). Consequently, different types of weathering, depending on site-specific characteristics such as rock types, depth to surface or climatic conditions, can alter the properties of the fractured system. St. Clair et al. (2015) provide an overview, including references, of these processes potentially developing new fractures of reactivated existing ones. In general, weathering results in disaggregation of the topmost part of the crystalline bedrock (saprolite) and the fracturing of the first several meters of the bedrock (saprock). Therefore, stress fields are an important boundary condition for groundwater flow and weathering in fractured crystalline bedrock (St. Clair et al. 2015), even though the interconnection between stress and hydraulic properties is site-specific (e.g. Baghbanan and Jing 2008). In a simplified way, the effect can be described as positive feedback of groundwater flow in opened and connected fractures and chemical weathering processes to regional stress fields, called self-organization (Ortoleva et al. 1987). As an additional consequence of chemical weathering of certain minerals, open fractured can be clogged-for example due to the abundance of clay minerals in the hosting rock (e.g. Wright 1992).

The specific profile of weathering (Fig. 2) depends on the site-specific characteristics including the properties of the bedrock, climatic conditions, and formation history. The landforms created by in situ weathering are as manifold as the site-specific characteristics ranging from profiles with sparsely localized disaggregated bedrock in glaciated regions 

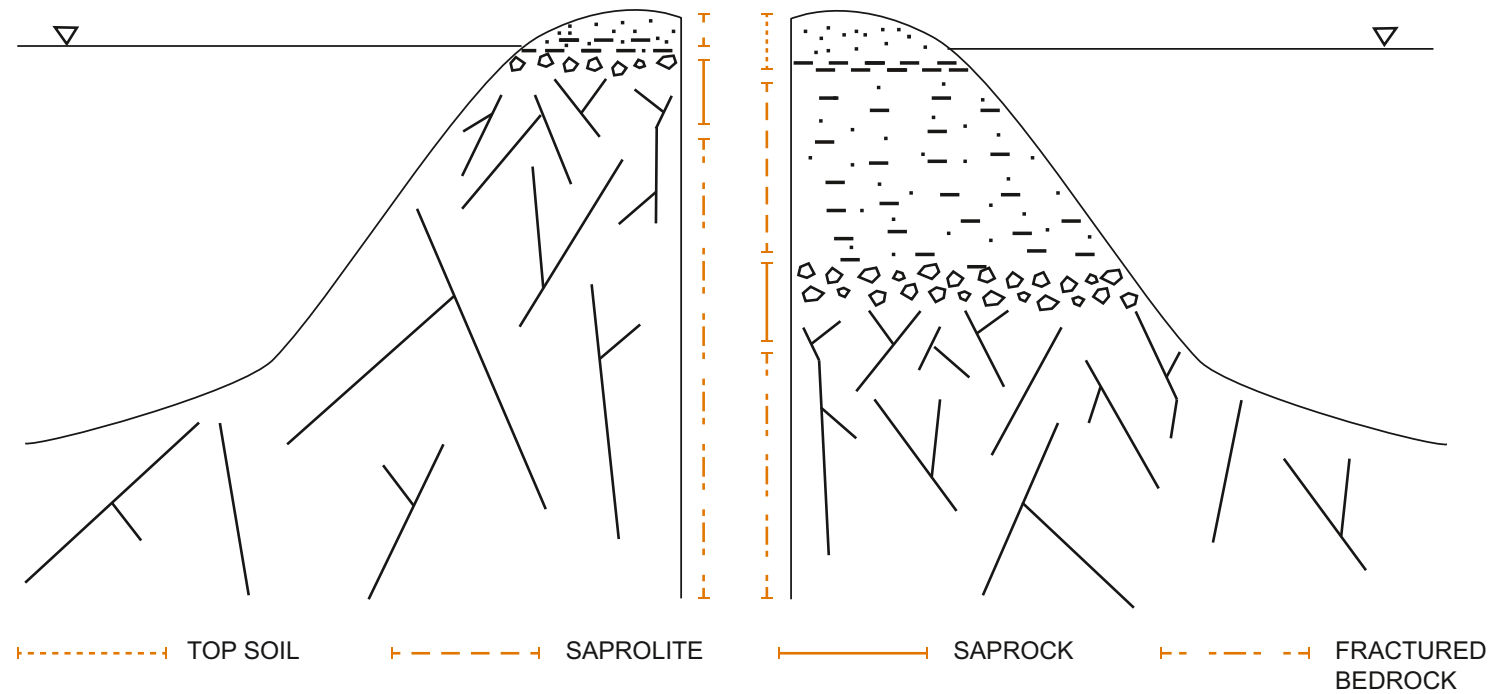

Fig. 2 Examples of the specific profile of weathering in $\mathbf{a}$ glaciated regions and $\mathbf{b}$ (sub)tropical regions

(Fredin et al. 2017), to deeply weathered basement rocks in tropical and subtropical regions (Wright 1992). Especially the weathering interface depth between saprolite and saprock (Fig. 2) has a direct influence on processes related to groundwater recharge and preferential horizontal groundwater flow (Nicolas et al. 2019). According to Lachassagne et al. (2001), the combination of a thick saprolite, a saprock with open vertical fractures and well-developed fractures in the basement rock creates a favourable system for enhanced groundwater flow, which on the other hand might also be prone to SWI. It can be concluded that a conclusive analysis of SWI in fractured crystalline bedrock needs to consider both the geological history and current in situ stress field (Larsson 1972; Sund and Bergman 1981).

The result of the impact on the crystalline bedrock over a geological timescale is a complex system with hydrogeological heterogeneity on different scales. Based on an analysis of 13,600 drilled wells from Sweden and Norway, Henriksen (2003) point out that there is no clear regional correlation of hydraulic conductivity and several local properties such as isostatic uplift rate, rock type, soil type, topography, or recharge; and he concludes additionally that no combination of these parameters is significant enough to explain the local variations in well yield. In general, the permeability of fractured crystalline bedrock ranges over several orders of magnitude (e.g. Rutqvist 2015; Worthington et al. 2016) and therefore can differ more within one bedrock type than between different bedrock types (Banks et al. 1996); this despite the fact that fissure patterns differ greatly depending on the rock type (e.g. Sund and Bergman 1981; Acworth 1987). However, the permeability of fractured crystalline rock is highly dominated by the conductance of single features and their density, length, and connectivity (Singhal and Gupta 2010). Flow occurs mainly in a small number of fractures (first and second order), depending on the host rock ranging from over $90 \%$ in granite to roughly $65 \%$ in basalt (Worthington et al. 2016). In contrast, unweathered crystalline bedrock has very low porosity and permeability (Acworth 1987); however, for this condition, hydraulic properties are barely reviewed and unknown (Hjerne and Nordqvist 2014). One exception is the rough correlation between hydraulic conductivity and porosity based on a large data analysis from different rock types by Guimerà and Carrera (2000).

\section{Case studies in fractured crystalline bedrock with special focus on SWI}

Werner et al. (2013) point out that fieldwork is a crucial factor in understanding the impact of aquifer heterogeneity on SWI; however, case studies on SWI in fractured crystalline bedrocks are scarce, with the exception being coastal areas dominated by basalt bedrock. Due to the high permeability of these volcanic rock aquifers, the properties are more similar to sedimentary bedrock (i.e. limestone and sandstone). Overviews on case studies and general conception that focused on groundwater circulation in young basaltic bedrock can be found in Hildenbrand et al. (2005) or Singhal and Gupta (2010). The main focus of the present article is on intrusive igneous and metamorphic rocks. Due to the low number of case studies available in international literature, the following overview also takes studies into account that deal with general regional flow patterns in fractured crystalline coastal bedrock and studies where SWI is only a side-aspect. Table 1 shows an overview of peer-reviewed articles related to SWI in fractured crystalline bedrock and links to Table 2, which lists different investigative techniques and methods used, or of potential use in coastal crystalline bedrock.

Most of the case studies related to SWI in fractured crystalline bedrock, except from Mälkki (2003) and Aretouyap et al. (2020), apply at least one analysis tool based on 

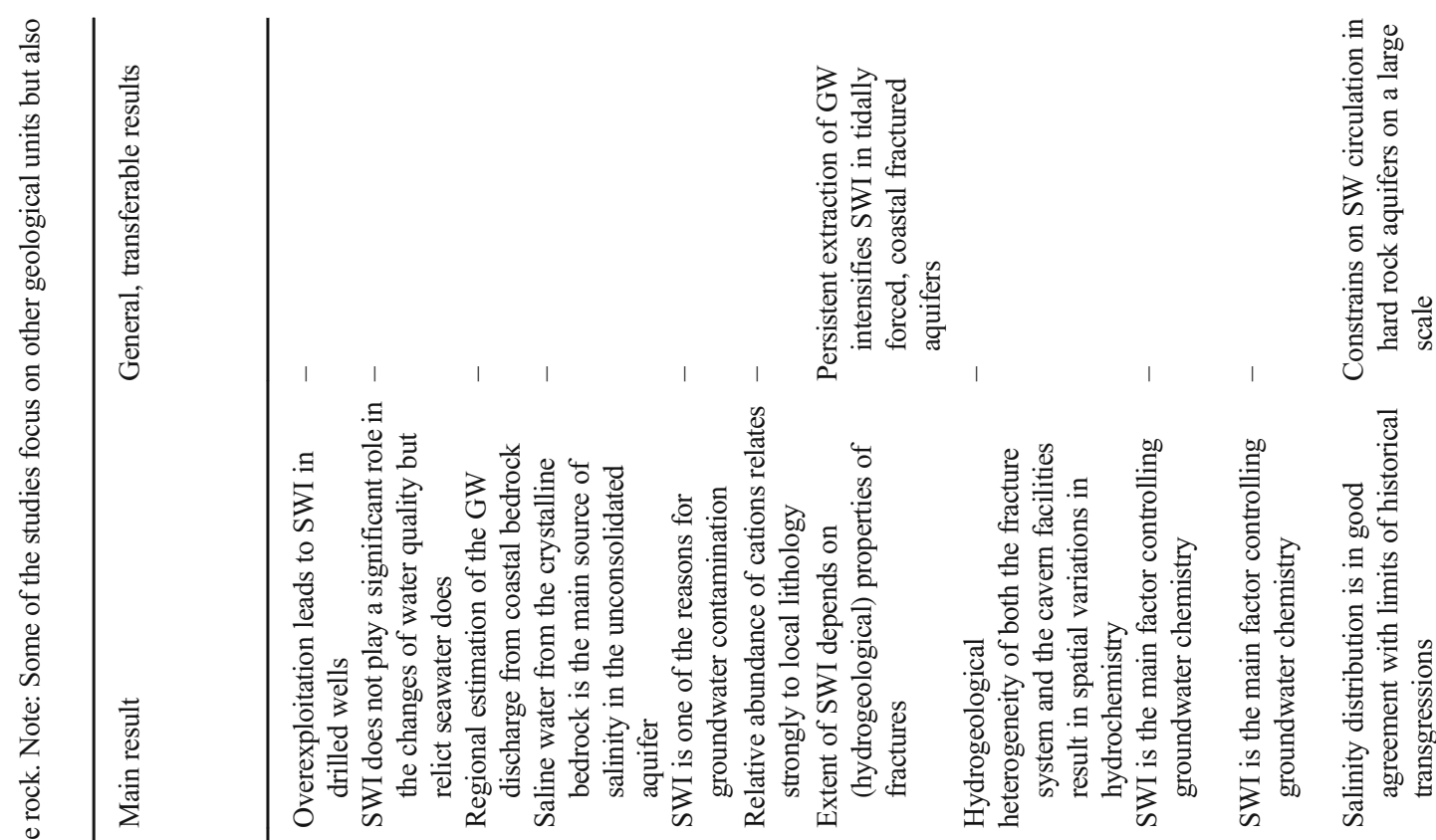

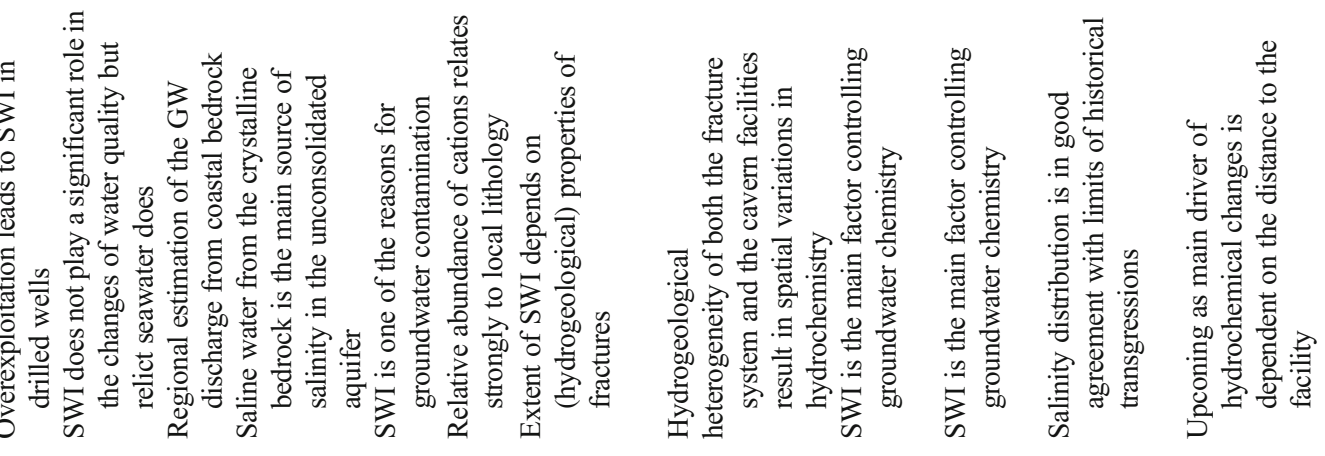

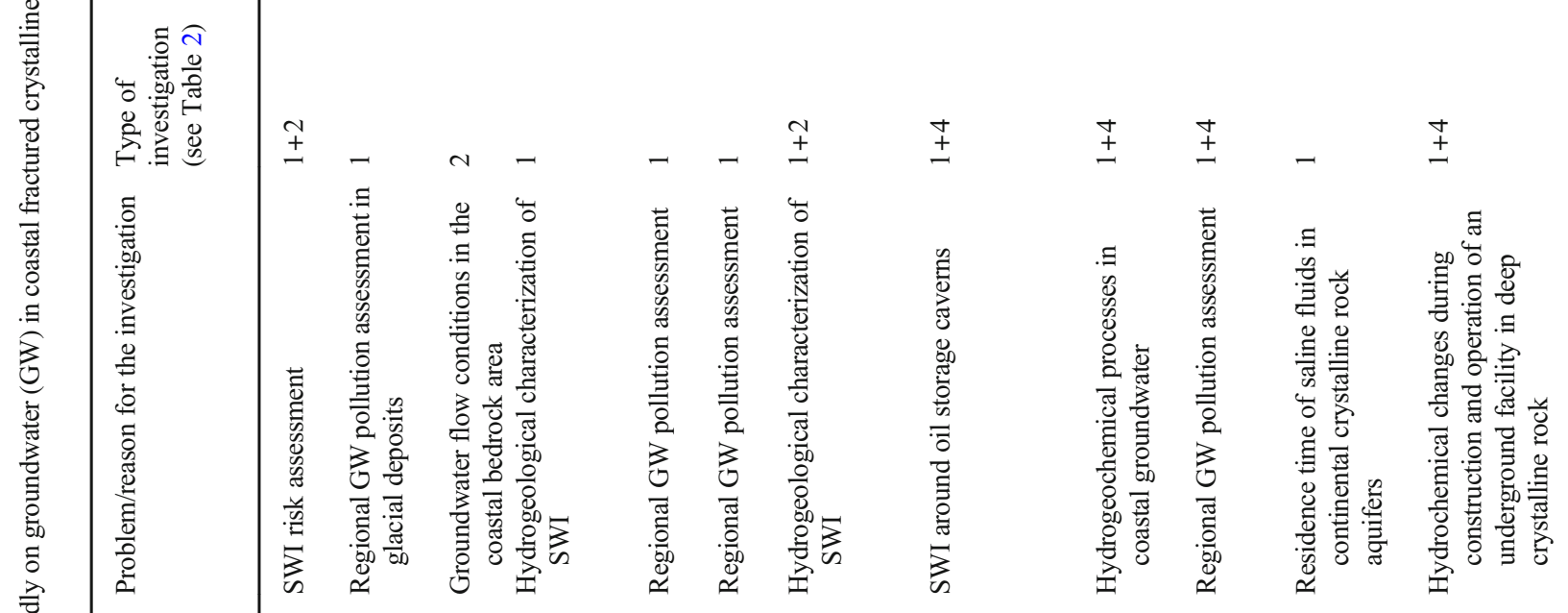

핶

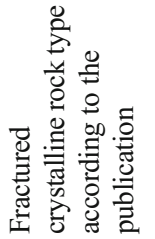

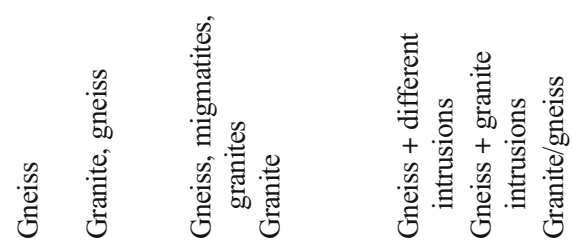

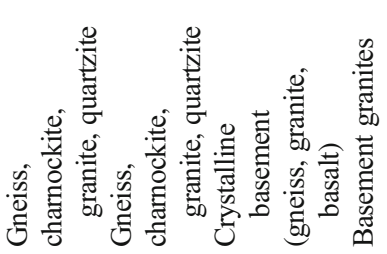

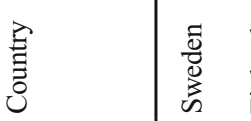

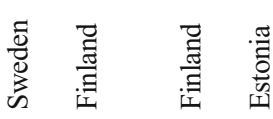

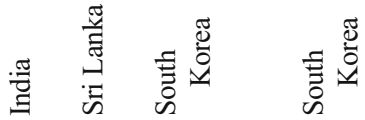

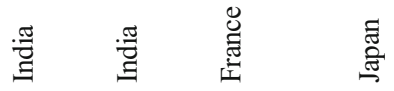

蛋

है 卷 言

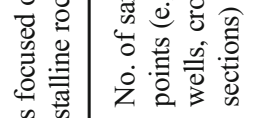

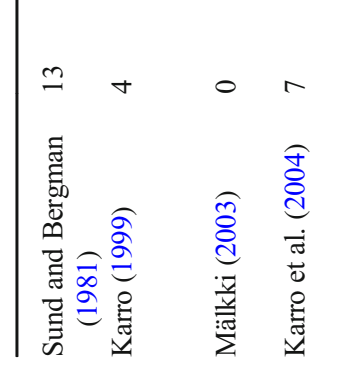

ㅇ

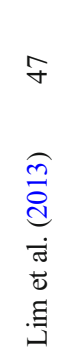

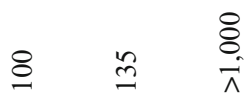

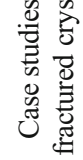

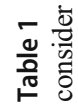
$\mid$

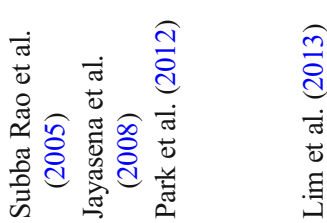

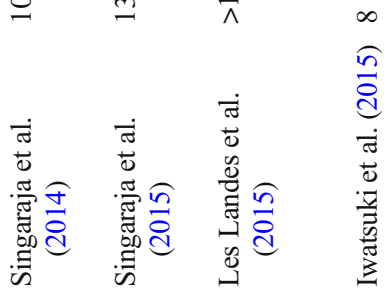




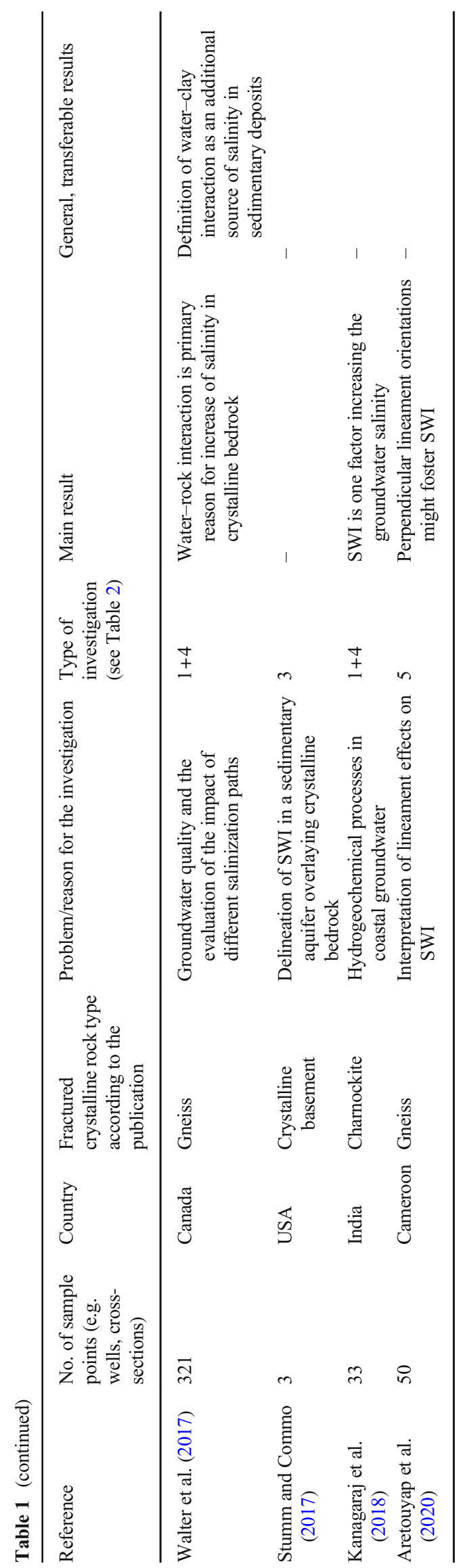

groundwater samples taken from different wells in coastal areas. The most common method applied is the analysis of major ions measured in the groundwater samples. Presented in either Piper diagrams (Piper 1944) or in different kinds of mass ratios (e.g. chloride/bromide), major ions are used to evaluate the water quality on a regional scale. At a point scale, Sund and Bergman (1981), Park et al. (2012), Les Landes et al. (2015) and Stumm and Como (2017) take chloride $\left(\mathrm{Cl}^{-}\right)$or electrical conductivity (EC) measurements or borehole logs along one or different wells. Stumm and Como (2017) combine the chloride measurements with borehole logs of focused electromagnetic induction but do not discuss the results in the deeper bedrock parts of the observed wells. Walter et al. (2017) extend the hydrogeochemical analysis by measuring minor and trace elements for a large dataset of over 300 water samples. The data set is the second largest of the case studies, only excelled by the enormous number (over 1,000 samples) considered by Les Landes et al. (2015). It must be noted that both studies do not exclusively include samples taken from fractured crystalline bedrock. This also influences the numbers of sampling points given in Table 1, which does not always represent the real numbers of sampling points related to fractured crystalline bedrock. The remaining studies base their regional analysis on two (Park et al. 2012) up to 135 (Singaraja et al. 2015) sample sites. These numbers should not be taken as quality measures since the variety of research aims and approaches between the case studies is vast (cf. Table 1). To extend the hydrogeochemical analysis, Lim et al. (2013) and Kanagaraj et al. (2018) sample stable isotopes additional to major ions to analyse the origin of the water in the coastal zone, and hence also the origin of salinity.

The majority of studies identify SWI as the main process that increases the groundwater salinity in the coastal area. Other processes worth mentioning here are mixing with relict seawater (Karro 1999; Karro et al. 2004; Les Landes et al. 2015) and water-rock interactions (Jayasena et al. 2008; Walter et al. 2017). In all cases, SWI is caused by groundwater extraction in the coastal area. Only Park et al. (2012) mention tidal influences as an additional process which is however intensified by groundwater pumping.

All studies listed in Table 1 focus on a larger scale and none on a single fracture or a fracture network with defined boundaries. In general, it can be noted that the description of fracture properties is, if at all, only a side aspect. Most studies give a general overview of the regional geology, and in exceptional cases, sometimes with hydrogeological properties of different units, e.g. hydraulic conductivity (Lim et al. 2013). Descriptions of the single fractures or fracture networks are generally incomplete and lacking basic properties, for example the orientation of the fractures. This also includes the lack of standard (structural) geology tools such as rose diagrams to indicate the general orientation(s) of fractures or stereographic projections. The most detailed description of the fractured 
Table 2 Summary of the methods used (based on Table 1) or of potential use for the study of SWI in crystalline bedrock

\begin{tabular}{|c|c|c|c|}
\hline ID & Field of research & Attribute under investigation & Method/techniques \\
\hline 1 & Hydrogeochemical characterisation & $\begin{array}{l}\text { - Isotopes } \\
\text { - Major ions } \\
\text { - Physicochemical parameters } \\
\text { - Trace elements }\end{array}$ & $\begin{array}{l}\text { - Chloride distribution (spatial/vertical) } \\
\text { - EC distribution (spatial/vertical) } \\
\text { - Graphical interpretation (e.g. molar ratio, Piper/Chadda plots, } \\
\text { sodium adsorption ratio) }\end{array}$ \\
\hline 2 & (Hydro)geological characterisation & $\begin{array}{l}\text { - Lineaments } \\
\text { - Hydrogeological parameter } \\
\text { - In situ stress } \\
\text { - Host rock/minerals }{ }^{\mathrm{a}}\end{array}$ & $\begin{array}{l}\text { - Orientation (e.g. rose diagram) } \\
\text { - Lineament density } \\
\text { - Fracture distribution map } \\
\text { - Borehole imaging } \\
\text { - Pumping test analysis } \\
\text { - Hydraulic splitting }{ }^{\mathrm{a}} \\
\text { - Thin section analysis } \\
\text { - Isotope analysis } \\
\text { - Fluid inclusion analysis } \\
\text { - Trace element analysis } \\
\text { - Redox front analysis } \\
\mathrm{a}^{\mathrm{a}}\end{array}$ \\
\hline 3 & Geophysics & $\begin{array}{l}\text { - Stratigraphy } \\
\text { - Rock texture and structure } \\
\text { - Lithology }\end{array}$ & $\begin{array}{l}\text { - Vertical electrical sounding (VES) } \\
\text { - Electromagnetic-induction Logging (EM) } \\
\text { - Flowing fluid electrical conductivity (FFEC) } \\
\text { - Proton magnetic resonance (PMR) }{ }^{\mathrm{a}} \\
\text { - Nuclear magnetic resonance (NMR) } \\
\text { - Electrical resistivity tomography }(\mathrm{ERT})^{\mathrm{a}}\end{array}$ \\
\hline 4 & Statistics and data analysis & - Parameters listed in 1 and 2 & $\begin{array}{l}\text { - Principal component analysis (PCA) } \\
\text { - Hierarchical cluster analysis (HCA) } \\
\text { - Correlation analysis } \\
\text { - Factor analysis } \\
\text { - Tidal oscillation analysis }\end{array}$ \\
\hline 5 & Remote sensing & - Earth surface & $\begin{array}{l}\text { - Satellite/aerial photographs } \\
\text { - LiDAR }\end{array}$ \\
\hline
\end{tabular}

${ }^{\text {a }}$ Methods of potential use for the study of SWI in crystalline bedrock

network is given by Mälkki (2003), who describes major and minor faults as well as fractures in orientation and inclination as well as permeability. Iwatsuki et al. (2015) present all information related to the fracture network in a cross-section of the area under investigation. Aretouyap et al. (2020) combined remote sensing and other different geological data to define the length and orientation of lineaments in order to make a preliminary delineation of SWI in fractured crystalline rock. Less detailed descriptions of the fracture systems can be found in Sund and Bergman (1981), Subba Rao (2005), Les Landes et al. (2015) and Walter et al. (2017), studies which all consider major faults in their assessments. Information regarding inclination of the faults are mostly missing with a few exceptions namely in Mälkki (2003), Iwatsuki et al. (2015) and Walter et al. (2017). Park et al. (2012) apply an acoustic televiewer in the two boreholes used in the field study to map the fractures around the boreholes. Based on this analysis, the authors conclude that the changes in the mixing zone extent are related to the location of conductive fractures. The weathering interface between saprolite and saprock is addressed in seven studies, whereby Karro et al. 2004, Subba Rao (2005), Jayasena et al. (2008), Les Landes et al. (2015) and Iwatsuki et al. (2015) quote former studies for the general depth of the interface, while Park et al. (2012) guessed the depth of the interface based on the casing of the bore wells. Furthermore, Kanagaraj et al. (2018) applies a geophysical approach (vertical electrical sounding) for the identification of the interface depth.

A few case studies apply additional approaches in order to define the spatial extent of SWI in fractured crystalline bedrock. The analysis of Park et al. (2012) is based on extensive analysis of a different kind of time series (e.g. drawdown curve, tidal oscillation). They also include classical borehole analysis such as pumping test analysis to obtain hydraulic conductivity in the vicinity of the bore wells. Additionally, Park et al. (2012) use high-frequency EC measurements, which they connect to tidal level measurement in the study region. Karro (1999), Singaraja et al. (2014) and Singaraja et al. (2015) make use of standard statistics (i.e. correlation analysis) adopted regarding major ion concentrations. In all cases, these methods are used as an additional tool, rather than a stand-alone approach, to analyse potential sources of contamination. Two of the studies also include a time perspective in the statistical analysis by analysing samples from different seasons or years (Karro 1999; Singaraja et al. 2014). Lim et al. (2013) and Walter et al. (2017) take the analysis one step further and apply advanced statistical tools to the ion measurements. Whereas Lim et al. (2013) used principle 


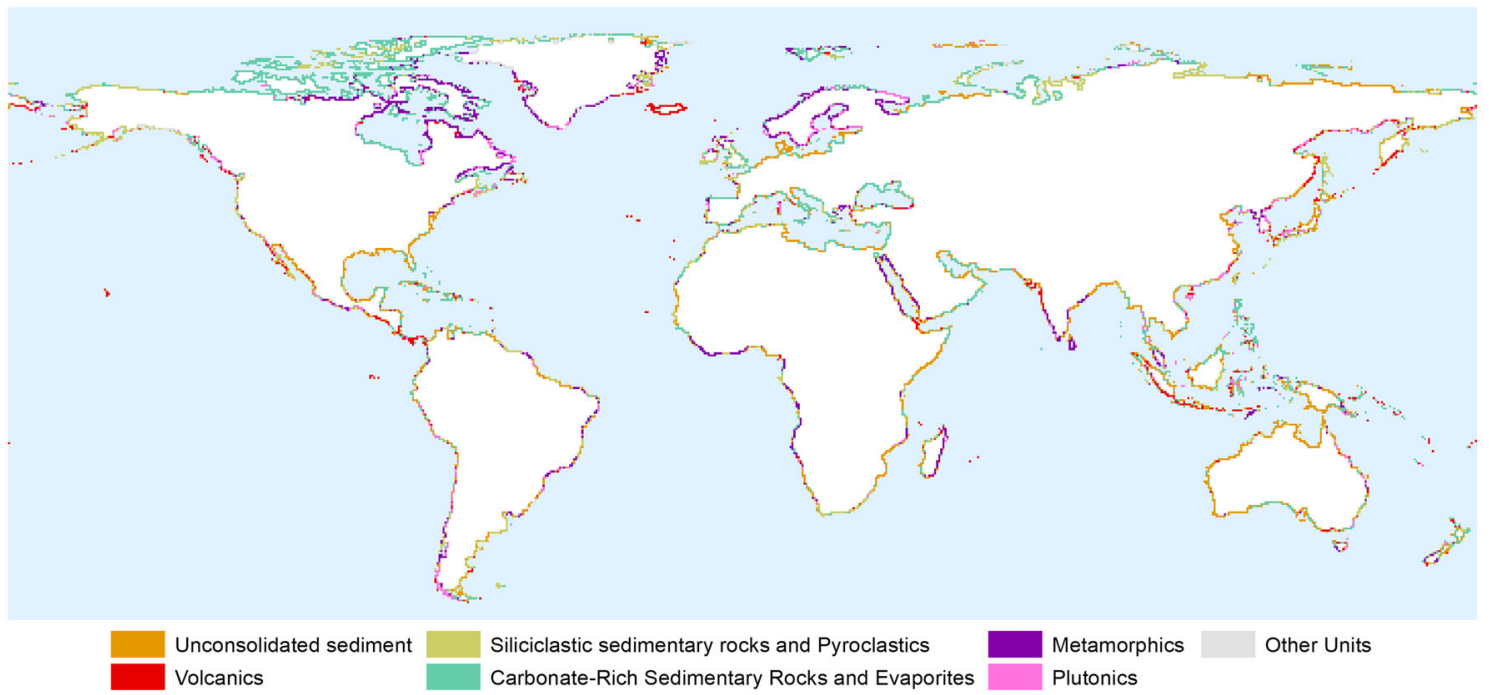

Fig. 3 Detailed map of the world coastal lithography (excluding Antarctica) based on the global lithological map GLiM (Hartmann and Mossdorf 2012)

component analysis (PCA) to identify different contamination sources, Walter et al. (2017) complete their analysis with a hierarchical cluster analysis (HCA); they link each of the clusters to a different kind of host rock and different processes altering the "background" concentration, thereby pointing out two different salinization sources.

The literature review reveals the variety of topics and applied approaches in the study of SWI in fractured crystalline bedrock; however, analyses of SWI in fractured crystalline bedrock are mostly connected to water management issues rather than fundamental research. Therefore, hydrogeochemical analysis is the most frequently applied analysis tool. To the knowledge of the authors, no fundamental research exists specifically focusing on the processes involved in SWI in fractured rock. Different to other groundwater flow processes, for example in deep crystalline bedrock, no specific field sites exist to study SWI. As mentioned by some of the studies, even water sampling can be a serious problem due to unavailability of observation wells, i.e. not used for groundwater pumping (e.g. Park et al. 2012; Walter et al. 2017). The poor data coverage in terms of geology and technical specification of the well (e.g. drilling depth and casing depth) adds to the problem (Walter et al. 2017). These circumstances complicate the interpretation of the results even further. The other major obstacle in the studies is the lack of information on the complexity of the highly conductive structures and the bedrock (e.g. Mälkki 2003; Les Landes et al. 2015), including the main hydraulic properties, the distribution in different areas, and the potential mechanisms influencing the chemical composition as well as the local and region flow system. To complete the hydrogeochemical interpretation of the results rather than to overcome this specific problem, Walter et al. (2017) suggest incorporating the chemical analysis of the host rock. Classical geological approaches such as thin section analysis, could help to define the specific composition of the host rock in the study region. Similar to the mineral composition of the rock, former processes influencing the chemical composition of the water (e.g. immobile water from earlier deposition) need to be accounted for (Les Landes et al. 2015).

\section{Insight from related fields of research}

The literature on both SWI in general and groundwater flow in crystalline bedrock is abundant. At the same time, studies directly focused on SWI in crystalline bedrock are still scarce as can be seen from the last section (on case studies). The studies identified through the literature review presented in Table 1 cover most of the coastal areas where crystalline bedrock is the dominating lithology (Fig. 1). Most of the field studies base their assessment of SWI on physicochemical characterization of water samples taken from wells, mainly used for water supply, i.e., pumped wells; however, boreholes run the risk of providing hydraulic shortcuts and therefore give a blended signal from different depths (Pool and Carrera 2011). The risk might be even more pronounced in fractured systems where wells can intersect highly conductive structures with different orientations and depths (e.g. Caswell 1979). Especially wells drilled for the purpose of local or larger-scale freshwater supply might tap different highly conductive features in order to maximize the well yield. The limited validity of borehole data on a larger scale is an additional disadvantage of analysis solely based on borehole data since SWI needs to be considered as a process of three dimensions (Abarca et al. 2007).

The risk of SWI in fractured crystalline bedrock is determined by historical and current stress fields as well as hydrogeochemical changes (i.e. dissolution, precipitation and remineralisation) within the fractures influencing local flow 
permeability (Tsang et al. 2015). Therefore, assessment of SWI in fractured crystalline bedrock needs to combine different methods accounting for the aforementioned processes. Allen et al. (2002) give a good example of addressing the problem of SWI in fractured sedimentary rocks on a larger scale, whereby they applied an integrated geophysical, geological and geochemical approach to investigate the potential SWI for a sedimentary bedrock aquifer in Western Canada. Recently, Banks et al. (2021) published a similar study investigating groundwater lens dynamics of a sedimentary bedrock island. To improve the knowledge on SWI in crystalline bedrock, it may thus be a valid approach to try and combine additional methods applicable for the study of SWI in fractured crystalline bedrock. This section indicates additional methods, which will be briefly presented. All methods applied in the studies of section 'Case studies in fractured crystalline bedrock with special focus on SWI' and the additional methods presented here, are summarized in Table 2.

\section{Geological approaches}

The importance of the geological history has been highlighted in several sections of this review. On a larger scale, or in remote areas, the application of remote sensing technologies to map geological and geomorphological features might be a first step in understanding the geological history of the area (e.g. Mabee et al. 1994; Henriksen and Braathen 2006; Vasuki et al. 2014; Schreiber et al. 2015). Independent of the approaches used to extract lineament information and analyse lineament properties, e.g. the fracture orientation by using rose diagrams, any remote sensing study needs to be validated by ground truthing (e.g. Schreiber et al. 2015). Further information on the topic can be found, for example, in the previously mentioned studies or in Sander (2007); however, due to the diversified history of crystalline bedrock, an investigation of the surface might not be sufficient to characterize the properties of fractures. Outcropping fractures most likely change their properties with depth due to the discussed processes of weathering, increasing stress and remineralization (Mabee et al. 1994), which once again shows the necessity of local or regional investigations.

Especially, regarding Nordic countries, investigations exist on the impact of geological history on groundwater flow or well productivity (e.g. Larsson 1972), due to the fact that groundwater in fractured crystalline bedrock not only plays in important part in water resources management (e.g. Earon and Olofsson 2020), but also in infrastructural aspects (e.g. Kitterød 2015). Several of these reports mention that current stress fields (e.g. due to isostatic uplift) overprint the fractured systems created by old tectonic stress fields (e.g. Rohr-Torp 1994; Gudmundsson et al. 2002). Current in situ stress can be determined by hydraulic splitting of the host rock, for example in borewells (Henriksen and Braathen 2006). This information combined with other geological information can be used as input variables for numerical models simulating the fracture growth (e.g. Gudmundsson et al. 2002). In combination with groundwater flow and hydrogeochemical models, these models could be used to describe the genesis of the fractured system and therefore define the hydrogeological properties of a system, an approach frequently used in karst hydrogeology (e.g. Gabrovšek and Dreybrodt 2001). Another method to determine the groundwater flow in fractured rocks is the injection of dye tracer, for example during drilling of a new well (e.g. Gustafsson and Andersson 1991). This approach can be combined with several other techniques, for example radar tomography (Day-Lewis et al. 2003), but are only valid on a small scale, i.e. along the flow paths.

\section{Geophysical approaches}

Several studies have proven the applicability of geophysical techniques in investigating SWI. In general, geophysical techniques are applied to locate the interface between freshwater and saltwater or to characterize aquifer heterogeneity both in unconsolidated (e.g. Lang et al. 2004; Luján and Romo 2010) and sedimentary bedrock (e.g. Allen et al. 2002; Comte et al. 2017). Due to the specific properties of fractured crystalline bedrock, the selection of possible methods is not as broad as for sedimentary aquifers. In general, the methods can be divided into two different types of approaches - the first one focuses on borehole logs and the description of the vicinity of the well, and the second one defines the properties on a larger scale. One method used to define certain properties from a borehole $\log$ is presented in Table 1. Stumm and Como (2017) apply electromagnetic-induction logging (EM) to estimate the chloride concentration, mainly in the glacial aquifer. With a high number of borehole logs, hydrological information can be achieved on a regional scale - for example, the thickness of saprolite and saprock as well as the depth of the weathering interface (e.g. Raji and Abdulkadir 2020). Several other techniques are available for the investigation and description of highly conductive structures along a bore well-for example flowing fluid electrical conductivity (FFEC; Tsang et al. 1990, 2016) to mention only one. Comprehensive overviews on the topic can be found in Keys (1996) or Spies (1996). In the absence of wells or to gain information on a large scale, other technique to investigate groundwater storage in bedrock can be used; one example is the study of Kanagaraj et al. (2018) who used vertical electrical sounding (VES). Other examples for this method can be found for example in Maiti et al. (2012 and 2013). Similar to the methods applied in boreholes, these techniques-e.g. electrical resistivity tomography (ERT), proton magnetic resonance (PMR), nuclear magnetic resonance (NMR) - are able to define the characteristics of saprolite, saprock and the interface between 
them (e.g. Griffiths and Barker 1993; Wyns et al. 2004). Some of these methods can be used in airborne specifications to map lineaments as well as to characterize the fractured bedrock properties in terms of hydrogeological characteristics (Chandra et al. 2019). Several other methods exist in the characterization of groundwater flow and storage and the general characterization of the bedrock (cf. Singhal and Gupta 2010); thus, this short summary should not be taken as an exhaustive overview.

\section{Geochemistry approaches}

The physicochemical properties of groundwater are the result of a combination of different processes depending on the system as well as a time component. In fractured crystalline bedrock, the properties are dominated by the rock type as well as potential fracture fillings. SWI or other sources of contamination (natural as well as anthropogenic) create multiple mixing combination on a regional scale. Therefore, most studies have a local acquisition with limited potential to be generalized. In general, geochemical analyses in fractured crystalline bedrock have to take two different time frames into account-a short one following the active flow path of the water from the recharge area to the coastal area, and a longer one of mostly stagnant flow paths. Several of the case studies point out that stagnant water, e.g. originated from previous transgressions, interferes with the active part of the flow system. Walter et al. (2017) present one of the studies analysing different flow paths from the origin to the sampled wells. Another study, including the flow path in crystalline fractured rock but focusing on groundwater in a coastal plain, is presented by Shi et al. (2018). In addition to the interaction with the bedrock, the authors also include different anthropogenic sources of contamination in their assessment. A similar kind of process description based on stable isotopes for deep-laying crystalline bedrock is presented by Kloppmann et al. (2002). The overview summarizes different processes in different parts of the world, altering the isotope compensation of saline water. Another approach to assess the regional history and therefore the characteristic properties of the crystalline bedrock based on geochemical measurements of the host rock is the so-called paleohydrogeology (e.g. Tullborg et al. 2008; Drake and Tullborg 2009). These methods combine several analyses of the minerals, for example the isotopic composition, fluid inclusion and thin section analysis.

\section{Conclusions}

The presented review of SWI in fractured crystalline bedrock reveals that the topic is generally addressed from very different angles. Most of the case studies that were identified through the review concern the water quality in coastal areas, where SWI is identified as the only or one of several potential contamination sources. The low number of studies carried out may indicate that this problem only is of local or, in general, of minor importance. Taking the abundance of crystalline bedrock in coastal areas and the magnitude of the globally emerging SWI problem into account, this seems to be unlikely. Thus, another explanation could be that studying SWI in fractured crystalline bedrock in a scientifically sound and publishable manor, requires a lot of effort as well as sophisticated methods, due to the complexity and heterogeneity of the hydrogeological setting. Investigating the current and future risk of SWI in fractured crystalline bedrock requires expertise and approaches from different research fields of geology, hydrogeology, hydrochemistry, geophysics and even others not mentioned here.

In particular, the characterization of the highly complex fractured system, including hydrodynamic characteristics, flow paths and possible entry points, requires a large investigative effort, which is not always feasible. This might be the reason that system complexity is frequently mentioned in the studies, but in most case studies not sufficiently addressed. The complexity of natural fracture systems might also explain the divergence between the number of case studies and numerical modelling approaches, where certain simplifications (most often in regards to the fracture system) are used to define the problem.

The holistic assessment of SWI in fractured crystalline bedrock needs to consider different kinds of processes on different timescales. The geological timescale is important to describe the system's specific characteristics as well as initial conditions (e.g. spatial distribution of salinity) for short-term processes with varying boundary conditions (i.e. sea level changes and recharge). Some of the short-term processes involved may be highly dynamic and evaluation of longer time series are required to capture their influence. The specific hydrogeological properties, which are a direct result of the history of the coastal area, and the wide variety of research questions that form the background of the respective study, lead to the broad variety of the applied approaches within the relatively few studies that could be identified. Therefore, a standard approach for investigating SWI that could be applied in a wide range of crystalline bedrock settings cannot be identified from the literature, making it difficult to compare or transfer results from one study to another.

The review highlights that SWI in fractured crystalline bedrock is or potentially could be a problem on almost all continents. In certain regions, for example the Nordic countries, the magnitude of the problem increases. Based on the coastal lithology, $22 \%$ of the world's coastline consists of either plutonic or metamorphic rock potentially hosting fracture systems, which justifies any effort to gain more data and hence a better understanding of the processes involved in SWI in fractured crystalline bedrock. 


\section{Appendix}

Table 3 Percentage of coastal lithography per continent. Lithography according to the first level lithological class of the Global Lithological Map (GLiM; Hartmann and Mossdorf 2012)

\begin{tabular}{|c|c|c|c|c|c|c|c|c|c|c|c|c|c|c|c|c|}
\hline \multirow{2}{*}{$\begin{array}{l}\text { Region } \\
{[\%]}\end{array}$} & \multicolumn{3}{|c|}{ Siliciclastic sediments } & \multicolumn{3}{|c|}{ Carbonate-rich sedimentary rocks and evaporites } & \multicolumn{3}{|c|}{ Volcanics } & \multicolumn{3}{|c|}{ Plutonics } & \multirow{2}{*}{$\begin{array}{l}\text { Meta-morphics } \\
\mathrm{mt}\end{array}$} & \multicolumn{3}{|c|}{ Other units } \\
\hline & $\mathrm{su}$ & ss & py & $\mathrm{sc}$ & $\mathrm{sm}$ & ev & va & vi & $\mathrm{vb}$ & pa & pi & $\mathrm{pb}$ & & $\mathrm{wb}$ & ig & nd \\
\hline N. America & 8 & 15 & 1 & 8 & 30 & 0 & 1 & 2 & 4 & 5 & 1 & 1 & 18 & 1 & 6 & 0 \\
\hline S. America & 24 & 24 & 1 & 3 & 10 & 0 & 1 & 1 & 3 & 12 & 2 & 1 & 14 & 1 & 0 & 0 \\
\hline Europe & 14 & 13 & 0 & 16 & 19 & 0 & 1 & 1 & 5 & 9 & 0 & 1 & 18 & 0 & 2 & 0 \\
\hline Africa & 33 & 20 & 0 & 13 & 5 & 0 & 0 & 0 & 4 & 2 & 0 & 0 & 22 & 0 & 0 & 0 \\
\hline Asia & 26 & 18 & 1 & 5 & 20 & 0 & 1 & 6 & 4 & 8 & 0 & 1 & 7 & 0 & 1 & 0 \\
\hline Australia & 44 & 12 & 1 & 11 & 12 & 0 & 1 & 2 & 4 & 3 & 1 & 2 & 5 & 1 & 0 & 0 \\
\hline World & 20 & 17 & 1 & 9 & 21 & 0 & 1 & 3 & 4 & 7 & 1 & 1 & 13 & 0 & 3 & 0 \\
\hline
\end{tabular}

$s u$ unconsolidated sediments; $s s$ siliciclastic sedimentary rocks; $p y$ pyroclastics; $s c$ carbonate sedimentary rocks; $s m$ mixed sedimentary rocks; $e v$ evaporites; $v a$ acid volcanic rocks; $v i$ intermediate volcanic rocks; $v b$ basic volcanic rocks; $p a$ acid plutonic rocks; $p i$ intermediate plutonic rocks; $p b$ basic plutonic rocks; $m t$ metamorphics; $w b$ water bodies; $i g$ ice and glaciers; $n d$ no data

Acknowledgements The authors thank associate editor Peter Kang and two anonymous reviewers for their constructive comments which helped to improve the manuscript.

Funding Open access funding provided by University of Gothenburg. This study was funded by the Swedish Geological Survey (SGU) under grant: SGU 36-2063/2016.

\section{Declarations}

Conflict of interest On behalf of all authors, the corresponding author states that there is no conflict of interest.

Open Access This article is licensed under a Creative Commons Attribution 4.0 International License, which permits use, sharing, adaptation, distribution and reproduction in any medium or format, as long as you give appropriate credit to the original author(s) and the source, provide a link to the Creative Commons licence, and indicate if changes were made. The images or other third party material in this article are included in the article's Creative Commons licence, unless indicated otherwise in a credit line to the material. If material is not included in the article's Creative Commons licence and your intended use is not permitted by statutory regulation or exceeds the permitted use, you will need to obtain permission directly from the copyright holder. To view a copy of this licence, visit http://creativecommons.org/licenses/by/4.0/.

\section{References}

Abarca E, Carrera J, Sánchez-Vila X, Voss CI (2007) Quasi-horizontal circulation cells in 3D seater intrusion. J Hydrol 339:118-129. https://doi.org/10.1016/j.jhydrol.2007.02.017

Acworth RI (1987) The development of crystalline basement aquifers in a tropical environment. Q J Eng Geol 20:265-272
Allen DM (2004) Sources of ground water salinity on islands using ${ }^{18} \mathrm{O}$, ${ }^{2} \mathrm{H}$ and ${ }^{34} \mathrm{~S}$. Ground Water 42(1):17-31

Allen DM, Abbey DG, Mackie DC, Luzitano RD, Cleary M (2002) Investigation of potential saltwater intrusion pathways in a fractured aquifer using an integrated geophysical, geological and geochemical approach. J Environ Eng Geophys 7(1):19-36

Aretouyap Z, Billa L, Jones M, Richter G (2020) Geospatial and statistical interpretation of lineaments: salinity intrusion in the KribiCampo coastland of Cameroon. Adv Space Res 66:844-853. https://doi.org/10.1016/j.asr.2020.05.002

Back W, Freeze RA (1983) Chemical hydrogeology. Benchmark Paper in Geology 73, Hutchinson Ross, Stroudsburg, PA

Baghbanan A, Jing L (2008) Stress effects on permeability in a fractured rock mass with correlated fracture length and aperture. Int J Rock Mech Mining Sci 45:1320-1334

Banks D, Odling NE, Skarphagen H (1996) Rohr-Torp E (1996) Permeability and stress in crystalline rocks. Terra Nova 8:223-235

Banks EW, Post VEA, Meredith K, Ellis J, Cahill K, Noorduijn S, Batelaan O (2021) Fresh groundwater lens dynamics of a small bedrock island in the tropics, northern Australia. J Hydrol 595: 125942. https://doi.org/10.1016/j.jhydrol.2020.125942

Barlow PM (2003) Ground water in fresh water-salt water environments of the Atlantic Coast. US Geol Surv Circ 1262

Barlow PM, Reichard EG (2010) Saltwater intrusion in coastal regions of North America. Hydrogeol J 18:247-260. https://doi.org/10.1007/ s10040-009-0514-3

Bear J (1979) Hydraulics of groundwater. McGraw-Hill, New York

Bense VF, Gleeson T, Loveless SE, Bour O, Scibek J (2013) Fault zone hydrogeology. Earth Sci Rev 127:171-192. https://doi.org/10.1016/ j.earscirev.2013.09.008

Berkowitz B (2002) Characterizing flow and transport in fractured geological media: a review. Adv Water Resour 25:861-884

Bodin J, Delay F, de Marsily G (2003a) Solute transport in a single fracture with negligible matrix permeability: 1 . fundamental mechanisms. Hydrogeol J 11:418-433. https://doi.org/10.1007/s10040$003-0268-2$ 
Bodin J, Delay F, de Marsily G (2003b) Solute transport in a single fracture with negligible matrix permeability: 2. mathematical formalism. Hydrogeol J 11:434-454. https://doi.org/10.1007/s10040003-0269-1

Caine JS, Evans JP, Forster CB (1996) Fault zone architecture and permeability structure. Geology 24(11):1025-1028

Carr PA (1969) Salt-water intrusion in Prince Edward Island. Can J Earth Sci 6:63-74

Carreira PM, Marques JM, Nunes D (2014) Source of groundwater salinity in coastline aquifers based on environmental isotopes (Portugal): natural vs. human interference - a review and reinterpretation. Appl Geochem 41:163-175

Caswell B (1979) Maine's ground-water situation. Groundwater 17(3): 235-243

Chandra S, Auken E, Maurya PK, Ahmed S, Verma SK (2019) Large scale mapping of fractures and groundwater pathways in crystalline Hardrock by AEM. Sci Rep 9:398. https://doi.org/10.1038/s41598018-36153-1

Comte J-C, Wilson C, Ofterdinger U, González-Quirós A (2017) Effect of volcanic dykes on coastal groundwater flow and saltwater intrusion: a field-scale multiphysics approach and parameter evaluation. Water Resour Res 53(3):2171-2198

Cooper HH (1959) A hypothesis concerning the dynamic balance of fresh water and salt water in a coastal aquifer. J Geophys Res 64(4):461467. https://doi.org/10.1029/JZ064i004p00461

Custodio E (2010) Coastal aquifers in Europe: an overview. Hydrogeol J 18:269-280. https://doi.org/10.1007/s10040-009-0496-1

Day-Lewis FD, Lane JW, Harris JM, Gorelick SM (2003) Time-lapse imaging of saline-tracer transport in fractured rock using differenceattenuation radar tomography. Water Resour Res 39(10):1290

Dentz M, Tartakovsky DM, Abarca E, Guadagnini A, Sanchez-Vila X, Carrera J (2006) Variable-density flow in porous media. J Fluid Mech 561:209-235. https://doi.org/10.1017/S00221120060000668

Dehls JF, Olesen O, Bungum H, Hicks EC, Lindholm CD and Riis F (2000) Neotectonic map: Norway and adjacent areas, 1:3,000,000. Geological Survey of Norway, Trondheim, Norway

Drabbe J, Badon-Ghijben W (1888) Nota in verband met de voorgenomen putboring nabij Amsterdam [Notes in connection with the proposed well drilling near Amsterdam]. Tijdschrift Koninklijk Instituut van Ingenieurs, The Hague, pp 8-22

Drake H, Tullborg E-L (2009) Paleohydrogeological events recorded by stable isotopes, fluid inclusions and trace elements in fracture minerals in crystalline rock, Simpevarp area, SE Sweden. Appl Geochem 24:715-732

Earon R, Olofsson B (2020) Integrating storage and spatial variability into shallow groundwater balances: moving towards water security in hard rock coastal areas. Hydrol Res 51(6):1293-1311. https://doi. org/10.1016/10.2166/nh.2020.054

Eronen M (2005) Land uplift: virgin land from the sea. In: Seppälä M (ed) The physical geography of Fennoscandia. Oxford University Press, Oxford, UK, pp 17-34

Etsias G, Hamill GA, Campbell D, Straney R, Benner EM, Aguila JF, McDonnell MC, Ahmed AA, Flynn R (2021) Laboratory and numerical investigation of saline intrusion in fractured coastal aquifers. Adv Water Resour 149:103866. https://doi.org/10.1016/j. advwatres.2021.103866

EU (2020) Directive (EU) 2020/2184 of the European Parliament and of the Council of 16 December 2020 on the quality of water intended for human consumption. Document 32020L2184, EU, Brussels

Evans JP, Foster CB, Goddard JV (1997) Permeability of fault-related rocks and implications for hydraulic structure of fault zones. J Struct Geol 19(11):1393-1404

Ferguson G, Gleeson T (2012) Vulnerability of coastal aquifers to groundwater use and climate change. Nat Clim Chang 2:342-345. https://doi.org/10.1038/nclimate1413
Fiorillo F, Petitta M, Preziosi E, Rusi S, Esposito L, Tallini M (2015) Long-term trend and fluctuations of karst spring discharge in a Mediterranean area (Central-Southern Italy). Environ Earth Sci 74: 153-172. https://doi.org/10.1007/s12665-014-3946-6

Fleury P, Bakalowicz M, de Marsily G (2007) Submarine springs and coastal karst aquifers: a review. J Hydrol 339:79-92. https://doi.org/ 10.1016/j.jhydrol.2007.03.009

Fredin O, Viola G, Zwingmann H, Sørlie R, Brönner M, Lie J-E, Grandal EM, Mueller A, Margreth A, Voigt C, Knies J (2017) The inheritance of a Mesozoic landscape in western Scandinavia. Nat Commun 8:14879. https://doi.org/10.1030/ncomms14879

Gabrovšek F, Dreybrodt W (2001) A model of the early evolution of karst aquifers in limestone in the dimensions of length and depth. J Hydrol 240(3-4):206-224. https://doi.org/10.1016/S0022-1694(00)00323-1

Gentry WM, Burbey TJ (2004) Characterization of ground water flow from a spring discharge in a crystalline rock environment. J Am Water Resour Assoc 40:1205-1217

Griffiths DH, Barker RD (1993) Two-dimensional resistivity imaging and modelling in areas of complex geology. J Appl Geophys 29(3-4):211-226

Gudmundsson A (2000) Active fault zones and groundwater flow. Geophys Res Lett 27(18):2993-2996

Gudmundsson A, Fjeldskaar I, Gjesdal O (2002) Fracture-generated permeability and groundwater yield. NGS Bull 439:61-69

Guihéneuf N, Bour O, Boisson A, Le Borgne T, Becker MW, Nigon B, Wajiduddin M, Ahmed S, Maréchal J-C (2017) Insights about transport mechanisms and fracture flow channeling from multi-scale observations of tracer dispersion in shallow fractured crystalline rock. J Contam Hydrol 206:18-33

Guimerà J, Carrera J (2000) A comparison of hydraulic and transport parameters measured in low-permeability fracture media. J Contam Hydrol 41:261-281

Gustafsson E, Andersson P (1991) Groundwater flow conditions in a lowangel fracture zone at Finnsjö, Sweden. J Hydrol 126:79-111

Hartmann J, Moosdorf N (2012) The global lithological map database GLiM: a representation of rock properties at the earth surface. Geophys Geosys 13:Q12004. https://doi.org/10.1029/ 2021GC004370

Herzberg A (1901) Die Wasserversorgung einiger Nordseebäder [The water supply of some North Sea spas]. J Gasbeleucht Wasserversorg 44:815-819

Henriksen H (2003) The role of some regional factors in the assessment of well yields from hard-rock aquifers of Fennoscandia. Hydrogeol J 11:628-645. https://doi.org/10.1007/s10040-003-0277-1

Henriksen H, Braathen A (2006) Effects of fracture lineaments and in-situ rock stresses on groundwater flow in hard rocks: a case study from Sunnfjord, western Norway. Hydrogeol J 14:441-461. https://doi. org/10.1007/s10040-005-0444-7

Hildenbrand A, Marlin C, Conroy A, Gillot P-Y, Filly A, Massault M (2005) Isotopic approach of rainfall and groundwater circulation in the volcanic structure of Tahiti-Nui (French Polynesia). J Hydrol 302:187-208. https://doi.org/10.1016/j.jhydrol.2004.07.006

Hjerne C, Nordqvist R (2014) Relation between mass balance aperture and hydraulic properties from field experiments in fractured rock in Sweden. Hydrogeol J 22:1285-1292. https://doi.org/10.1007/ s10040-014-1132-2

Houben G, Post VEA (2017) The first field-based description of pumping-induced saltwater intrusion and upconing. Hydrogeol J 25:234-247. https://doi.org/10.1007/s1040-016-1476-x

Idowu TE, Lasisi KH (2020) Seawater intrusion in the coastal aquifers of east and horn of Africa: a review from a regional perspective. Sci Afri 8:e00402. https://doi.org/10.1016/j.sciaf.2020.e00402

Iwatsuki T, Hagiwara H, Ohmori K, Munemoto T, Onoe H (2015) Hydrochemical disturbances measured in groundwater during the construction and operation of a large-scale underground facility in 
deep crystalline rock in Japan. Environ Earth Sci 74:3041-3057. https://doi.org/10.1007/s12665-015-4337-3

Jasechko S, Perrone D, Seybold H, Fan Y, Kirchner JW (2020) Groundwater level observations in 250,000 coastal US wells reveal scope of potential seawater intrusion. Nat Commun 11:3229. https:// doi.org/10.1038/s41467-020-17038-2

Jayasena HAH, Chandrajith R, Dissanayake CB (2008) Hydrogeochemistry of the groundwater flow system in a crystalline terrain: a study from the Kurunegala district, Sri Lanka. Environ Geol 55:723-730. https://doi.org/10.1007/s00254-007-1024-z

Jeen S-W, Kang J, Jung H, Lee J (2021) Review of seawater intrusion in western coastal regions of South Korea. Water 13:761. https://doi. org/10.3390/w13060761

Kanagaraj G, Elango L, Sridhar SGD, Gowrisankar G (2018) Hydrogeochemical processes and influence of seawater intrusion in coastal aquifers of Chennai, Tamil Nadu, India. Environ Sci Pollut Res 25:8989-9011. https://doi.org/10.1007/s11356-0170910-5

Karro E (1999) Long-term changes in groundwater chemistry in four coastal water supply plants in southern Finland. Boreal Environ Res 4:175-186

Kerrou J, Renard PA (2010) A numerical analysis of dimensionality and heterogeneity effects on advective dispersive seawater intrusion processes. Hydrogeol J 18(1):55-72. https://doi.org/10.1007/s10040009-0533-0

Karro E, Marandi A, Vaikmäe R (2004) The origin of increased salinity in the Cambrian-Vendian aquifer system on the Kopli Peninsula, northern Estonia. Hydrogeol J 12:424-435

Keys WS (1996) A practical guide to borehole geophysics in environmental investigations. CRC, Boca Raton, FL

Kitterød N-O (2015) Archaeological deposits and tunnel constructions: simulation of groundwater head at the old wharf of Bergen, Norway. Quatern Int 368:51-67. https://doi.org/10.1016/j.quaint.2014.10. 045

Kloppmann W, Girard J-P, Négrel P (2002) Exotic stable isotope compositions of saline waters and brines from crystalline basement. Chem Geol 184:49-70

Lachassagne P, Wyns R, Bérard P, Bruel T, Chéry L, Coutand T, Desprats J-F, Le Strat P (2001) Exploitation of high-yield in hardrock aquifers: downscaling methodology combining GIS and multicriteria analysis to delineate field prospecting zones. Groundwater 39(4):568-581

Lang M, Reichard EG, Crawford SM, Everett RR, Newhouse MW, Williams CF (2004) Ground-water quality of coastal aquifer systems in the West Coast Basin, Los Angeles County, California, 19992002. US Geological Survey Scientific Investigations Report, 5067

Larsson I (1972) Ground water in granite rocks and tectonic models. Nord Hydrol 3:111-129

Les Landes AA, Aquillina P, Davy P, Vergnaud-Ayraud V, Carlier L (2015) Timescales of regional circulation of saline fluids in continental crystalline rock aquifer (Armorican Massif, western France). Hydrol Earth Syst Sci 19:1413-1426

Lim J-W, Lee E, Moon HS, Lee K-K (2013) Integrated investigation of seawater intrusion around oil storage caverns in a coastal fracture aquifer using hydrogeochemical and isotopic data. J Hydrol 486: 202-210. https://doi.org/10.1016/j.jhydrol.2013.01.023

Llopis-Albert C, Pulido-Velazquez D (2014) Discussion about the validity of sharp-interface models to deal with seawater intrusion in costal aquifers. Hydrol Process 28:3642-3654. https://doi.org/10.1002/ hyp. 9908
Lu C, Luo J (2010) Dynamics of freshwater-seawater mixing zone development in dual domain formations. Water Resour Res 46: W11601. https://doi.org/10.1029/2010WR009344

$\mathrm{Lu}$ C, Werner AD (2013) Timescales of seawater intrusion and retreat. Adv Water Resour 59:39-51. https://doi.org/10.1016/j.advwatres. 2013.05.005

Lu C, Kitanidis PK, Luo J (2009) Effects of kinetic mass transfer and transient flow conditions on widening mixing zones in coastal aquifers. Water Resour Res 45:W12402. https://doi.org/10.1029/ 2008WR007643

Lu C, Chen Y, Zhang C, Luo J (2013) Steady-state freshwater-seawater mixing zone in stratified coastal aquifers. J Hydrol 505:24-34. https://doi.org/10.1016/j.hydrol.2013.09.017

Luján V, Romo JM (2010) Audiomagnetotelluric investigation of seawater intrusion using 2-D inversion of invariant impedances. Geol Acta 8(1):51-66. https://doi.org/10.1344/105.000001515

Mabee SB, Hardcastle KC, Wise DU (1994) A method of collecting and analyzing lineaments of regional-scale fractured-bedrock aquifer studies. Groundwater 32(6):884-894

MacQuarrie KTB, Mayer KU (2005) Reactive transport modeling in fractured rock: a state-of-the-science review. Earth-Sci Rev 72(34):189-227. https://doi.org/10.1016/j.earscirev.2005.07.003

Maiti S, Erram VC, Gupta G, Tiwari EK (2012) ANN based inversion of DC resistivity data for groundwater exploration in hard rock terrain of western Maharashtra (India). J Hydrol 464(465):294-308. https:// doi.org/10.1016/j.jhydrol.2012.07.020

Maiti S, Gupta G, Erram VC, Tiwari RK (2013) Delineation of shallow resistivity structure around Malvan, Konkan region, Maharashtra by neutral network inversion using vertical electrical sounding measurements. Environ Earth Sci 68:779-794

Manivannan V, Elango L (2019) Seawater intrusion and submarine groundwater discharge along the Indian coast. Environ Sci Pollut Res 26:31592-31608. https://doi.org/10.1007/s11356-019-06103-z

Maxe L (2007) Enskild vattenförsörjning: kunskapsunderlag inför uppföljning av ett nytt delmål [Individual water supply: knowledge base for follow-up of a new sub-goal]. SGU-report 10, SGU, Uppsala, Sweden

Mälkki E (2003) Groundwater flow conditions in the coastal bedrock area of the Gulf of Finland. Geol Q 47(3):299-306

Mehdizadeh SS, Karamalipour SE, Asoodeh R (2017) Sea level rise effects on seawater intrusion into layered coastal aquifers [Simulation using dispersive and sharp-interface approaches]. Ocean Coastal Manage 138:11-18. https://doi.org/10.1016/j. ocecoaman.2017.01.001

Michael H, Mulligan A, Harvey C (2005) Seasonal oscillations in water exchange between aquifers and the coastal ocean. Nature 436(25). https://doi.org/10.1038/nature03935

Nicolas M, Bour O, Selles A, Dewandel B, Bailly-Comte V, Chandra S, Ahmed S, Maréchal J-C (2019) Managed aquifer recharge in fractured crystalline rock aquifers: impact of horizontal preferential flow on recharge dynamics. J Hydrol 572:717-732. https://doi.org/10 1016/j.jhydrol.2019.04.003

Ohlsson Y, Neretnieks I (1995) Literature survey of matrix diffusion theory and of experiments and data including natural analogues. Technical report 95-12, Swedish Nuclear Fuel and Waste Management Co., Stockholm

Ortoleva P, Merino E, Moore C, Chadam J (1987) Geochemical selforganization I: reactive transport feedbacks and modelling approaches. Am J Sci 287:979-1007

Park H-Y, Jang K, Ju JW, Yeo IW (2012) Hydrogeological characterization of seawater intrusion in tidally-forced coastal fractured bedrock 
aquifer. J Hydrol 446-447:77-89. https://doi.org/10.1016/j.jhydrol. 2012.04.033

Piper A (1944) A graphic procedure in the geochemical interpretation of water-analyses, transactions. Am Geophys Union 25(6):914-928. https://doi.org/10.1029/TR025i006p00914

Pool M, Carrera J (2011) A correction factor to account for mixing the Ghyben-Herzberg and critical pumping rate approximations of seawater intrusion in coastal aquifers. Water Resour Res 47:W05506. https://doi.org/10.1029/2010WR010256

Post VEA (2005) Fresh and saline groundwater interaction in coastal aquifers: is our technology ready for the problems ahead? Hydrogeol J 13:120-123. https://doi.org/10.1007/s10040-004$0417-2$

Post VEA, Abarca E (2010) Preface: saltwater and freshwater interaction in coastal aquifers. Hydrogeol J 18:1-4. https://doi.org/10.1007/ s10040-009-0561-9

Post VEA, Werner AD (2017) Coastal aquifers: scientific advances in the face of global environmental challenges. J Hydrol 551:1-3. https:// doi.org/10.1016/j.hydrol.2017.04.046

Raji WO, Abdulkadir KA (2020) Evaluation of groundwater potential of bedrock aquifers in geological sheet 223 Ilorin, Nigeria, using geoelectric sounding. Appl Water Sci 10:220. https://doi.org/10.1007/ s13201-020-01303-2

Reilly TE, Goodman AS (1985) Quantitative analysis of saltwaterfreshwater relationship in groundwater systems: a historical perspective. J Hydrol 80:125-160

Reilly TE, Goodman AS (1987) Analysis of saltwater upconing beneath a pumping well. J Hydrol 89:169-204

Rohr-Torp E (1994) Present uplift rates and groundwater potential in Norwegian hard rocks. NGU-Bull 426:47-52

Roques et al (2014) Hydrological behavior of a deep sub-vertical fault in crystalline basement and relationship with surrounding reservoirs. J Hydrol 509:42-54. https://doi.org/10.1016/j.hydrol.2013.11.023

Rutqvist J (2015) Fractured rock stress permeability relationship from in situ data and effects of temperature and chemical-mechanical couplings. Geofluids 15:48-66. https://doi.org/10.1111/gfl.12089

Sander P (2007) Lineaments in groundwater exploration: a review of application and limitations. Hydrogeol J 15:71-74. https://doi.org/ 10.1007/s10040-006-0318-9

Sayers CM (1990) Stress-induced fluid flow anisotropy in fractured rock. Transp Porous Media 5:287-297

Schreiber T, Fredin O, Viola G, Jarna A, Gasser D, Łapińska-Viola R (2015) Manual extraction of bedrock lineaments from highresolution LiDAR data: methodological bias and human perception. https://doi.org/10.1080/11035897.2015.1085434

Sebben ML, Werner AD, Graf T (2015) Seawater intrusion in fractured coastal aquifers: a preliminary numerical investigation using a fractured Henry problem. Adv Water Resour 85:93-108. https://doi.org/ 10.1016/j.advwatres.2015.09.013

Shi L, Jiao JJ (2014) Seawater intrusion and coastal aquifer management in China: a review. Environ Earth Sci 72:2811-2819

Shi X, Wang Y, Jiao JJ, Zhong J, Wen H, Dong R (2018) Assessing major factors affecting shallow groundwater. J Geochem Explor 184:17-27. https://doi.org/10.1016/j.gexplo.2017.10.003

Siena M, Riva M (2018) Groundwater withdrawal in randomly heterogeneous coastal aquifers. Hydrol Earth Syst Sci 22:2971-2985. https:// doi.org/10.5194/hess-22-2971-2018

Singaraja C, Chidambaram S, Prasanna V, Thivya C, Thilagavathi R (2014) Statistical analysis of the hydrogeochemical evolution of groundwater in hard rock coastal aquifers of Thoothukudi district in Tamil Nadu, India. Environ Earth Sci 71:451-464. https://doi.org/ 10.1007/s12665-013-2453-5
Singaraja C, Chidambaram S, Anandhan P, Prasanna V, Thivya C, Thilagavathi R (2015) A study on the status of saltwater intrusion in the coastal hard rock aquifer of South India. Environ Dev Sustain 17:443-475. https://doi.org/10.1007/s10668-014-9554-5

Singhal BBS, Gupta RP (2010) Applied hydrogeology of fractured rocks. Springer, Heidelberg, Germany

Spies BR (1996) Electrical and electromagnetic borehole measurements: a review. Surv Geophys 17:517-556

Snow DT (1965) A parallel plate model of fractured permeable media. $\mathrm{PhD}$ Thesis, Univ. of California, Berkeley, CA

St. Clair J, Moon S, Holbrook S, Perron T, Riebe S, Martel SJ, Carr S, Harman C, Singha K, deB Richer D (2015) Geophysical imaging reveals topographic stress control of bedrock weathering. Science 350(6260):534-538. https://doi.org/10.1126/science.aab2210

Stumm F, Como MD (2017) Delineation of salt water intrusion through use of electromagnetic-induction logging: a case study in southern Manhattan Island, New York. Water 9:631. https://doi.org/10.3390/ w9090631

Subba Rao N, Saroja Nirmala I, Suryanarayana K (2005) Groundwater quality in a coastal area: a case study from Andrah Pradesh, India. Environ Geol 48:543-550. https://doi.org/10.1007/s00254-005$1306-2$

Sund B, Bergman G (1981) Sea water intrusion in drilled wells. SWIM 7: $45-58$

Svanström S (2012) Varannan svensk Bor nära Havet [Every other Swede lives near the sea]. SCB, Välfärd 2/20212

Taylor GI (1953) Dispersion of soluble matter in solvent flowing slowly through a tube. Proc Royal Soc London Series A 219(1137):186203

Tremblay JJ, Cruz JD, Anger H (1973) Salt water intrusion in the Summerside Area, P.E.I. Ground Water 11(2)

Tsang CF, Neretnieks I (1998) Flow channeling in heterogeneous fractured rocks. Rev Geophys 36(2):275-298

Tsang CF, Hufschmied P, Hale FV (1990) Determination of fracture inflow parameters with a borehole fluid conductivity logging method. Water Resour Res 26:561-578

Tsang CF, Neretnieks I, Tsang Y (2015) Hydrologic issues associated with nuclear waste repositories. Water Resour Res 51:6923-6972. https://doi.org/10.1002/2015WR017641

Tsang CF, Rosberg J-E, Sharma P, Berthet T, Juhlin C, Niemi A (2016) Hydrological testing during drilling: application of the flowing fluid electrical conductivity (FFEC) logging method to drilling of a deep borehole. Hydrogeol J 24:1333-1341. https://doi.org/10.1007/ s10040-016-1405-z

Tsang YW, Tsang CF (1989) Flow channeling in a single fracture as a two-dimensional strongly heterogeneous permeable medium. Water Resour Res 25(9):2076-2080

Tullborg E-L, Drake H, Sandström B (2008) Paleohydrogeology: a methodology based on fracture mineral studies. Appl Geochem 23:18811897

Vasuki Y, Holden E-J, Kovesi P, Micklethwaite S (2014) Semi-automatic mapping of geological structures using UAV-based photogrammetric data: an image analysis approach. Comput Geosci 69:22-32

Walter J, Chesnaux R, Cloutier V, Gaboury D (2017) The influence of water/rock-water/clay interactions and missing in the salinization processes of groundwater. J Hydrol 13:168-188. https://doi.org/ 10.1016/10.1016/j.ejrh.2017.01.004

Werner AD (2010) A review of seawater intrusion and its management in Australia. Hydrogeol J 18:281-285

Werner AD, Bakker M, Post VEA, Vanderbohede A, Lu C, AtaieAshtiani B, Simmons CT, Barry DA (2013) Seawater intrusion processes, investigation and management; Recent advances and future 
challenges. Adv Water Resour 51:3-26. https://doi.org/10.1016/j. advwatres.2012.03.004

Worthington SRH, Davies GJ, Alexander (Jr.) EC (2016) Enhancement of bedrock permeability by weathering. Earth Sci Rev 160:188-202. https://doi.org/10.1016/j.earscirev.2016.07.002

Wright EP (1992) The hydrogeology of crystalline basement aquifers in Africa. In: Burgess WG (ed) Hydrogeology of crystalline basement aquifers in Africa. Geol Soc Spec Publ 66:1-27

Wyns R, Baltassat J-M, Lachassagne P, Legchenko A, Vaironi J, Mathieu F (2004) Application of proton magnetic resonance soundings to groundwater reserve mapping in weathered basement rocks (Brittany, France). Bull Soc Géol France 175(1):21-34
Xue Y, Wu J, Lui P, Wang J, Jiang Q, Shi H (1993) Sea-water intrusion in the coastal area of Laizhou Baz, China: 1. distribution of sea-water intrusion and its hydrochemical characteristics. Ground Water 31(4):532-537

Zhou Q, Lui H-H, Molz FJ, Zhang Y, Bodvarsson GS (2007) Field-scale effective matrix diffusion coefficient for fractured rock: results from literature survey. J Contam Hydrol 93:161-118

Publisher's note Springer Nature remains neutral with regard to jurisdictional claims in published maps and institutional affiliations. 